Quarterly Journal of Economics and Economic Policy

2014 VOLUME 9 ISSUE 2, June

p-ISSN 1689-765X, e-ISSN 2353-3293

www.economic-policy.pl

Stępniak-Kucharska A. (2014), Regional Differences in Innovation Activities of Industrial Enterprises in Poland, "Equilibrium. Quarterly Journal of Economics and Economic Policy", Volume 9, Issue 2, pp. 7392, DOI: http://dx.doi.org/10.12775/EQUIL.2014.012

\author{
Anna Stępniak-Kucharska*
}

University of Lodz, Poland

\title{
Regional Differences in Innovation Activities of Industrial Enterprises in Poland
}

JEL Classification: $O 31, O 32, D 22$

Keywords: innovation, enterprise, regional differences

\begin{abstract}
The aim of this paper is to examine regional differences in innovation activities of Polish enterprises in 2004-2010 on the basis of statistical data published by the CSO. The survey covered such issues as: expenditures on innovation activities (level and structure), the share of innovation-active enterprises, the types of innovations, as well as the objectives and effects of innovation policy.

The analysis shows that: the level of innovativeness of the Polish economy is still underdeveloped, the innovation structure is wrong (companies allocate most of their funds in the purchase of fixed assets, and only about 10\% on R\&D), Polish companies are selling too few (and ever fewer) innovative products.

The disparities between the expenditure on innovative activities in different voivodeships are significant. Three groups of voivodeships can be distinguished - highly innovative (Lower Silesian, Masovian, Pomeranian, Silesian), moderately innovative, and poorly innovative (Podlaskie, Świętokrzyskie, Warmian-Masurian, Lubush, Opolskie and West Pomeranian). In addition, the disparities between the most and least innovative voivodeships are increasing.
\end{abstract}

(C) Copyright Institute of Economic Research \& Polish Economic Society Branch in Toruń Date of submission: April 2, 2013; date of acceptance: November 27, 2013

* Contact: stepniak@uni.lodz.pl, Department for Economic Mechanism, University of Lodz, ul. Rewolucji 1905 r. Nr 41, 90-214 Łódź, Poland 


\section{Introduction}

The transition of modern economies from the industrial to cognitive phase makes knowledge and innovation the main source of sustainable economic growth. Innovation is nowadays a key instrument to stimulate economic growth and development, affecting also the form and structure of international business cooperation. The rate and scope of developing and implementing innovations has become regarded as one of the most important, if not the most important, accelerator of long-term competitiveness of enterprises, regions or entire countries.

The aim of the paper is to examine regional disparities in innovation activities of Polish industrial enterprises in the years 2004-2010.

The study covered such issues as: expenditures on innovation activities (level and structure), the share of innovation-active enterprises, the types of innovations, and the objectives and effects of innovation policy.

\section{Methodology of the research}

The analysis was conducted on the basis of statistical data published by the Central Statistical Office of Poland (CSO) - GUS - in: "Innovation Activity of Enterprises" and "Science and Technology" in the period 2005-2012. Studies providing the presented data on innovation activity were conducted within the framework of Community Innovation Survey. The entities participating in surveys were selected on the basis of the PKD 2007, which is consistent with the Statistical classification of economic activities in the European Community (NACE Rev. 2).The surveys covered enterprises which conducted activities of required profile, employing more than 9 people. However, in the years 2008-2010, the surveys covered a full population of entities fulfilling such criteria.

\section{The concept of innovation}

In literature, the concept of innovation has not been clearly defined. The concept is extensive in its nature as it is an interdisciplinary category, which is the subject of research of many scientific disciplines such as social science, humanities or science studies. Even within social sciences, innovation is defined differently by an economist, a financier or a management and marketing specialist. Generally, innovation can be defined as "the introduction of something new" or as "a novelty" (Słownik, 2013). 
The concept of innovation was introduced into economic literature by an Austrian economist J.A. Schumpeter, who distinguished two concepts: invention and innovation (Schumpeter, 1960, p. 104). Invention is making a new technical discovery, whereas innovation is its practical application in industry. Thus, not every invention is an innovation, since not every invention is introduced into the market.

According to Schumpeter, innovation defined widely as a concept includes all the new possible changes in production and distribution, in particular:

- introduction of a new product into the market,

- introduction of a new production method,

- opening of a new market (entry into a new market),

- acquisition of new source of raw materials or semi-finished products,

- introduction of new organisational solutions.

The gist of the so widely defined concept of innovation is the term "new". Schumpeter equated innovation with the first application of the given solution, not with its dissemination (imitation) (Niedzielski, Rychlik, 2006, p. 19).

From the point of view of this paper, the definition of innovation presented in The Oslo Manual (2005) is relevant as it comprises a set of rules on the measurement and interpretation of data in the field of science, technology and innovation. According to the Manual, innovation activity is "all scientific, technological, organisational, financial and commercial steps which actually lead, or are intended to lead, to the implementation of innovations". According to the wide definition, "innovation is the implementation of a new or significantly improved product (good or service) or process, a new marketing method or a new organisational method in business practice, workplace organisation or external relations". According to the narrow definition, innovation is "the implementation of one or more types of innovations". The Manual also specified the concept of "novelty" of introduced solutions. New solutions include the solutions that a company has developed as the first, as well as those that have been learnt from other companies or entities.

Analysing the concept of innovation presented in economic literature, a few approaches to the concept can be seen. Innovation is defined in the broad or narrow sense. In the first case, innovation is an invention that has been applied, while in the latter case, it is the entire management process resulting in the launch of novelties (compare: Stępniak-Kucharska, 2012). The presented definitions also differ in the meaning assigned to the concept (Baruk, 2006, p. 95). From the functional perspective, the process nature of innovation is emphasised (conscious changes). The attribute perspective comes down to the managerial approach (one of the possible responses to 
changes), whereas the institutional perspective applies to the whole set of methods and procedures.

To sum up, innovation is every new solution introduced in any of the areas of the company. This novelty can apply to the enterprise itself, as well as to the market and economy in which it operates.

\section{The importance of innovation policy in the European Union}

The exceptional importance of innovation policy has already been highlighted in the Lisbon Strategy, which set the goal for 2010 of making Europe the most competitive and dynamic, knowledge-based economic region, which is capable of sustainable economic growth, offering more and better jobs and greater social cohesion. These goals were to be achieved by means of:

- creating the information society,

- creating the European Research and Innovation Area,

- fostering the creation and development of business innovation,

- economic reforms supporting the development of the functional internal market,

- increasing efficiency and integration of financial markets,

- coordinating macroeconomic policies, fiscal consolidation and improving public finances of the Member States (Szomburg, 2004, p. 14).

Therefore, extensive scientific research in innovative, modern fields of knowledge serving as a source of development were to play the main role in these changes. Unfortunately, the implementation of the Strategy became very difficult, and in the case of some of its objectives even impossible.

In 2010, the European Union adopted another ten-year strategy (Europe 2020) which, on the one hand, is a continuation of the Lisbon provisions and, on the other, a response to the current economic crisis. These goals are to be achieved by means of:

- smart growth - knowledge and innovation based development,

- sustainable growth - competitive economy, effectively utilising resources,

- inclusive growth - social, economic and territorial cohesion, accompanied by a high level of employment (compare: Wolak-Tuzimek, WolakKozera, 2012, pp. 192-193).

Also in this case, one of the main three objectives of the Community policy is the development of economy based on knowledge and innovation (smart growth). The realisation of this objective is to result in improvement of conditions for conducting research and development activities by the 
Member States, among others, by allocating 3\% of GDP to investments in R\&D (Europe Strategy 2020, 2010, p. 5).

\section{Expenditures on innovation activities}

In the years 2000-2010, the expenditures of Polish industrial enterprises on innovation activities showed an upward trend1, as in that period those expenditures increased almost twofold - from 12.2 billion PLN to 22.4 billion PLN (GUS, 2005-2012). The continuing trend of steadily growing expenditures for this purpose resulted in Poland rating among the top ten EU countries with the highest expenditures on innovation activities in 20102.

The analysis of regional differences in expenditures on innovation activities indicates great disparities in this area (see Table 1). As previously indicated, global expenditures on innovation incurred by industrial companies showed an upward trend. A detailed analysis, however, indicates that this trend was evident only in the case of the Masovian Voivodeship. A steady decline in expenditures on innovation activities can be observed in five voivodeships (Lubush, Opole, Świętokrzyskie, Warmian-Masurian and Greater Poland). Additionally, in the case of the first three voivodeships, the expenditures in 2010 were lower than in 2002 (respectively by $17.1 \%, 31.1 \%$, $46.4 \%)$.

This trend is very unfavourable since in the case of these five voivodeships the expenditures on innovation activities were not only the lowest in the country, but were also steadily declining. The Lodz Voivodeship is also noteworthy as in 20083 expenditures on innovation increased almost five fold and it ranked at number three after the Masovian and Silesian Voivodeship.

In the years 2002-2010, only five voivodeships incurred expenditures on innovation that exceeded the average for the entire country (Lower Silesian, Masovian, Pomeranian, Silesian and Greater Poland). The Masovian Voivodeship was characterised by the highest level of expenditures for this purpose, which in 2010 reached the level four times exceeding the national average. The following voivodeships were characterised by the lowest level of expenditures on innovation: Lubush, Opole, Podlaskie, Świętokrzyskie, Warmian-Masurian and West Pomeranian.

\footnotetext{
${ }^{1}$ Innovation activities occured only in 2001 (reduction 6\%), 2005 (6\%) and 2009 (9.6\%).

${ }^{2}$ Included expenditures of Polish industrial and services enterprises on innovation activities for the acquisition of: $\mathrm{R} \& \mathrm{D}$, knowledge from external sources, software, machinery and technical equipment, means of transport, appliances and chattels.

${ }^{3}$ In the case of the Lodz and Podlaskie voivodeships - lack of some data for the year 2010 .
} 
Table 1. Expenditures on innovation activity in the years 2002-2010 (in mln zloty)

\begin{tabular}{|l|r|r|r|r|r|}
\hline Voivodeship & \multicolumn{1}{|c|}{$\mathbf{2 0 0 2}$} & $\mathbf{2 0 0 4}$ & \multicolumn{1}{c|}{$\mathbf{2 0 0 6}$} & \multicolumn{1}{c|}{$\mathbf{2 0 0 8}$} & \multicolumn{1}{c|}{$\mathbf{2 0 1 0}$} \\
\hline Greater Poland & 1507.6 & 1388.8 & 1714.8 & 1615.3 & 1535.1 \\
\hline Kuyavian-Pomeranian & 669.8 & 647.5 & 875.8 & 1836.4 & 1075.3 \\
\hline Lesser Poland & 879.1 & 1118.5 & 1341.7 & 1294.7 & 1083.5 \\
\hline Lodz & 507.3 & 507.3 & 454.3 & 2395.2 & b.d. \\
\hline Lower Silesian & 1278.4 & 1016.1 & 1220.1 & 1813.5 & 1729.7 \\
\hline Lublin & 541.1 & 354.2 & 562.7 & 826.1 & 544.4 \\
\hline Lubush & 280.5 & 361.8 & 239.8 & 357.5 & 262.8 \\
\hline Masovian & 1992.5 & 4204.6 & 4022.0 & 5100.8 & 6182.0 \\
\hline Opole & 296.3 & 369.9 & 315.8 & 292.0 & 265.2 \\
\hline Podlaskie & 185.1 & 246.4 & 458.3 & 445.5 & b.d. \\
\hline Pomeranian & 690.8 & 705.1 & 982.9 & 2261.5 & 1909.7 \\
\hline Silesian & 2962.1 & 2598.6 & 3753.3 & 4310.9 & 4037.8 \\
\hline Subcarpathian & 659.3 & 702.6 & 937.8 & 978.4 & 937.9 \\
\hline Świętokrzyskie & 793.1 & 324.4 & 307.3 & 450.2 & 332.7 \\
\hline Warmian-Masurian & 231.6 & 204.8 & 323.9 & 310.5 & 256.2 \\
\hline West Pomeranian & 373.4 & 639.4 & 330.7 & 395.4 & 530.2 \\
\hline AVERAGE & $\mathbf{8 6 5 . 5}$ & $\mathbf{9 6 3 . 6}$ & $\mathbf{1 1 1 5 . 1}$ & $\mathbf{1 5 4 2 . 8}$ & $\mathbf{1 4 8 4 . 9}$ \\
\hline
\end{tabular}

Source: GUS ${ }^{\mathrm{A}}$ (2005-2006), GUS ${ }^{\mathrm{B}}$ (2008-2012).

In the years 2004-2010, two trends can be observed in the area of innovation spending. Firstly, the percentage of companies that allocated funds for this purpose systematically decreased (a drop of $6.2 \mathrm{pp}$.). Secondly, even though there were fewer and fewer such entities, the average level of expenditures incurred by these entities increased (an increase of 79.3\%) (see Table 2).

The analysis of regional disparities indicates that in the years 2006-2010 the highest percentage of industrial enterprises incurring expenditures on innovation was in the Subcarpathian and Masovian Voivodeship, whereas the lowest in the Lodz Voivodeship. A negative phenomenon is a decline in the share of innovation-active companies in all the voivodeships. The largest drop was observed in the case of the Pomeranian Voivodeship (13.2 pp), the Subcarpathian (10.1 pp), Opole (9.0 pp) and Lower Silesian (8.4 pp) Voivodeships. However, the smallest decline (below $4 \mathrm{pp}$ ) was recorded in five voivodeships (West Pomeranian, Warmian-Masurian, Lodz, Lubush and Greater Poland). Moreover, only in two voivodeships - Lubush and Warmian-Masurian, the share of innovation-active companies in 2010 was higher than in 2008 (respectively by $1.7 \mathrm{pp}$ and $0.1 \mathrm{pp}$ ), however, as previously noted, this percentage was lower than in 2006. 
The decline in the share of enterprises with expenditures on innovation activity was accompanied, however, by an increase in the average expenditure on innovation activity. The highest increase of expenditures on innovation was recorded in the Masovian Voivodeship (an increase of 12,300 PLN and $125 \%$ ). The Masovian and Lodz Voivodeship were characterised by the highest level of expenditure for this purpose (per one enterprise), whereas the lowest level was recorded in the Warmian-Masurian, Opole, Podlaskie and Lubush Voivodeships. The difference between the worst and best voivodeship in 2010 was 10,700 PLN (86\%).

Table 2. Industrial enterprises with expenditures on innovation activity in the years 2006-2010 (in \%, in zloty)

\begin{tabular}{|l|c|c|c|c|r|r|}
\hline \multirow{2}{*}{ Voivodeship } & \multicolumn{4}{|c|}{ \% of total enterprises } & \multicolumn{3}{c|}{$\begin{array}{c}\text { Average expenditures for } \\
\text { one enterprise with } \\
\text { innovation activity (in th. zł) }\end{array}$} \\
\cline { 2 - 8 } & $\mathbf{2 0 0 6}$ & $\mathbf{2 0 0 8}$ & $\mathbf{2 0 1 0}$ & $\mathbf{2 0 0 6}$ & $\mathbf{2 0 0 8}$ & \multicolumn{1}{c|}{$\mathbf{2 0 1 0}$} \\
\hline Greater Poland & 17.1 & 15.9 & 13.3 & 3029.7 & 2838.8 & \multicolumn{1}{|c|}{3120.2} \\
\hline Kuyavian-Pomeranian & 18.1 & 17.1 & 14.1 & 3560.2 & 5886.0 & 4353.4 \\
\hline Lesser Poland & 18.4 & 18.2 & 13.7 & 3321.0 & 832.0 & 3273.5 \\
\hline Lodz & 13.4 & 11.2 & 10.0 & 1385.1 & 843.7 & 10837.7 \\
\hline Lower Silesian & 22.4 & 19.0 & 14.0 & 2664.0 & 4093.7 & 5561.7 \\
\hline Lublin & 21.4 & 17.6 & 15.1 & 2325.3 & 4589.4 & 4323.7 \\
\hline Lubush & 15.0 & 9.8 & 11.5 & 1700.4 & 3613.2 & 2576.2 \\
\hline Masovian & 19.6 & 19.8 & 13.4 & 5502.1 & 7055.1 & 12363.9 \\
\hline Opole & 24.5 & 17.0 & 15.5 & 1986.0 & 2335.0 & 2285.8 \\
\hline Podlaskie & 22.3 & 19.7 & 13.9 & 3419.9 & 3592.4 & 2406.3 \\
\hline Pomeranian & 25.8 & 19.1 & 12.6 & 2194.0 & 6145.5 & 8092.0 \\
\hline Silesian & 24.8 & 19.0 & 17.3 & 4473.5 & 59215.0 & 6193.0 \\
\hline Subcarpathian & 26.2 & 18.0 & 16.1 & 2649.1 & 3584.1 & 4060.1 \\
\hline Świętokrzyskie & 19.2 & 16.0 & 13.1 & 2119.0 & 3462.8 & 3080.6 \\
\hline Warmian-Masurian & 18.1 & 14.7 & 14.8 & 1564.7 & 1774.4 & 1685.5 \\
\hline West Pomeranian & 14.8 & 14.9 & 12.8 & 2029.0 & 1986.7 & 3708.0 \\
\hline POLAND & $\mathbf{2 0 . 0}$ & $\mathbf{1 7 . 1}$ & $\mathbf{1 3 . 8}$ & $\mathbf{3 2 0 6 . 0}$ & $\mathbf{4 7 5 7 . 0}$ & $\mathbf{5 7 4 9 . 7}$ \\
\hline
\end{tabular}

Source: GUS ${ }^{\mathrm{B}}$ (2008-2012).

Over the analysed period, expenditures on innovation per one enterprise decreased in only two voivodeships (Podlaskie - a decline of 30\%, Lesser Poland - a drop of $1 \%$ ). 


\section{Innovation activities}

Innovation activity of enterprises has a significant impact on innovation potential of the economy and individual regions. The innovation-active enterprise is the enterprise which "during the analysed period implemented at least one product or process innovation or implemented at least one innovative project that was withdrawn or abandoned in the analysed period (was not successful) or was not completed till the end of this period (i.e. it is still continued)" (GUS ${ }^{\mathrm{B}}$ 2012, p. 19).

Over the period of the six analysed years, the percentage of innovationactive entities decreased steadily (from 23.2\% in the years 2004-2006 to $17.1 \%$ in the years 2008-2010) (see: Table 3 ).

Table 3. Innovative enterprises in industry in the years 2004-2010 (in \%)

\begin{tabular}{|l|c|c|c|}
\hline Voivodeship & 2004-2006 & 2006-2008 & 2008-2010 \\
\hline Greater Poland & 19.9 & 18.8 & 16.2 \\
\hline Kuyavian-Pomeranian & 20.0 & 20.6 & 17.9 \\
\hline Lesser Poland & 21.3 & 22.8 & 16.3 \\
\hline Lodz & 19.0 & 15.0 & 13.4 \\
\hline Lower Silesian & 25.7 & 24.7 & 16.6 \\
\hline Lublin & 24.3 & 21.1 & 17.1 \\
\hline Lubush & 17.7 & 14.7 & 15.9 \\
\hline Masovian & 23.4 & 25.8 & 17.3 \\
\hline Opole & 28.6 & 22.9 & 19.3 \\
\hline Podlaskie & 25.8 & 25.0 & 17.0 \\
\hline Pomeranian & 28.5 & 25.1 & 15.3 \\
\hline Silesian & 26.4 & 22.6 & 20.3 \\
\hline Subcarpathian & 30.2 & 22.6 & 20.7 \\
\hline Świętokrzyskie & 22.1 & 20.2 & 16.5 \\
\hline Warmian-Masurian & 23.0 & 18.3 & 18.6 \\
\hline West Pomeranian & 18.8 & 17.2 & 15.5 \\
\hline POLAND & $\mathbf{2 3 . 2}$ & $\mathbf{2 1 . 4}$ & $\mathbf{1 7 . 1}$ \\
\hline
\end{tabular}

Source: GUS ${ }^{\mathrm{B}}$ (2008-2012).

In the years 2004-2006, the highest number of innovation-active enterprises were located in the Subcarpathian (30.2\%), Opole (28.6\%) and Pomeranian $(28.5 \%)$ Voivodeships, while the lowest number in the Lubush Voivodeship (17.7\%). At the same time, in half of the voivodeships, the share of innovation-active enterprises was higher than in the entire country. The following years were characterised by a decline in innovation activity of enterprises. In the years of 2008-2010, the greatest number of innovative compa- 
nies could be found in the Subcarpathian (20.7\%) and Silesian (20.3\%) Voivodeships, and the fewest in the Lodz Voivodeship (13.4\%). It is also worth noting that during this period only two regions recorded an increase in innovation activity (Lubush and Warmian-Masurian). However, in both cases, the number of innovative entities decreased compared to the years 20042006.

\section{Types of innovation activity}

According to the so-called linear model of innovation, innovation activity is identified with innovative research and development. However, at present this approach is considered inappropriate due to its very narrow scope $-\mathrm{R} \& \mathrm{D}$ is only one area of business innovation. The modern approach to innovation (the system model) sees innovation as a result of many complex relationships between individuals, organisations and the environment in which they operate (European Commission, 2003). Thus, innovation activity goes far beyond the area of R\&D, including financial expenditures (current ones and investments) incurred in the area of:

- research and development activities,

- purchase of knowledge from external sources,

- purchase of software,

- purchase of fixed assets,

- training of personnel,

- marketing,

- organisational methods (more in: Stępniak-Kucharska, 2012).

In the years 2000-2010, Polish industrial enterprises allocated most of their investment expenditures to purchase fixed assets (approx. 80\% of the total investment expenditure), particularly to purchase machinery and equipment. R\&D expenditures constituted only approx. $10 \%$ of the expenditures. A steady increase (since 2005) in the level of expenditures for this purpose is a positive phenomenon as it resulted in the $R \& D$ expenditures in 2010 exceeding the level of 2000 and reaching 14\%. The remaining funds were allocated for the purchase of knowledge and software, training, marketing activities and other purposes (GUS ${ }^{\mathrm{A}}$ 2005-2011).

The results of research on innovation indicate that in all the voivodeships expenditures on innovation were allocated primarily to investment (see Table 4). Enterprises from the Lodz (94\% in 2008), Podlaskie (92\% in 2008), Opole (92\%) and Warmian-Masurian (90\%) voivodeships allocated the largest part of funds for this purpose. However, the smallest share of expenditures on investment was recorded in the Lubush Voivodeship (58\%). Nevertheless, a decrease in the level and share of expenditures for this purpose is 
clearly visible. In 2010, compared to 2008, only the Opole Voivodeship recorded an increase in the share of expenditures on investment (from $78 \%$ to $92 \%$ ). In the remaining voivodeships, that drop ranged from $28 \mathrm{pp}$ (Lubush) to $1 \mathrm{pp}$ (Kuyavian-Pomeranian).

In the years 2008-2010, in comparison to 2006, the expenditures on investment were reduced in eight voivodeships (Lower Silesian, Lubush, Lublin, Subcarpathian, Silesian, Świętokrzyskie, Warmian-Masurian and Great Poland).

$R \& D$ expenditures are another item of expenditure on innovation, though much smaller. The largest part of funds for this purpose was allocated by entities from the Silesian (29.6\% - 2010) and Lesser Poland (20.4\% - 2010) Voivodeships. Research and development activities were less significant in the case of companies from the Warmian-Masurian $(2.3 \%$ - 2010), West Pomeranian $(4.2 \%$ - 2010) and Opole $(4.4 \%$ - 2010) Voivodeships. Moreover, only these three voivodeships recorded a decline in the importance of $R \& D$ expenditures in 2010. The low level (and share) of R\&D is an unfavourable condition, as it may mean a decrease in the research potential of Polish enterprises.

The companies allocated a marginal part of the funds to other types of innovation expenditures (acquisition of knowledge and software, training, marketing activities, etc.). The low level (and share) of expenditures on the purchase of knowledge from external sources seems to be particularly unfavourable in this situation. The exception in this respect was only the Voivodeship of Lublin which allocated more than $1 / 4$ of its funds in 2010 to the purchase of knowledge from external sources. However, a slight increase in spending for this purpose in most of the voivodeships (Lower Silesian, Kuyavian-Pomeranian, Lubush, Lodz (2008), Masovian, Subcarpathian, Pomeranian and Świętokrzyskie), is a positive development. A particularly unfavourable situation can be observed in the Warmian-Masurian Voivodeship, in which the expenditures on R\&D account for a small (and declining) proportion of funds allocated to innovation activities as the expenditures for this purpose reached 0.1 million zloty, which constituted $0.03 \%$ of the funds allocated to innovation. 


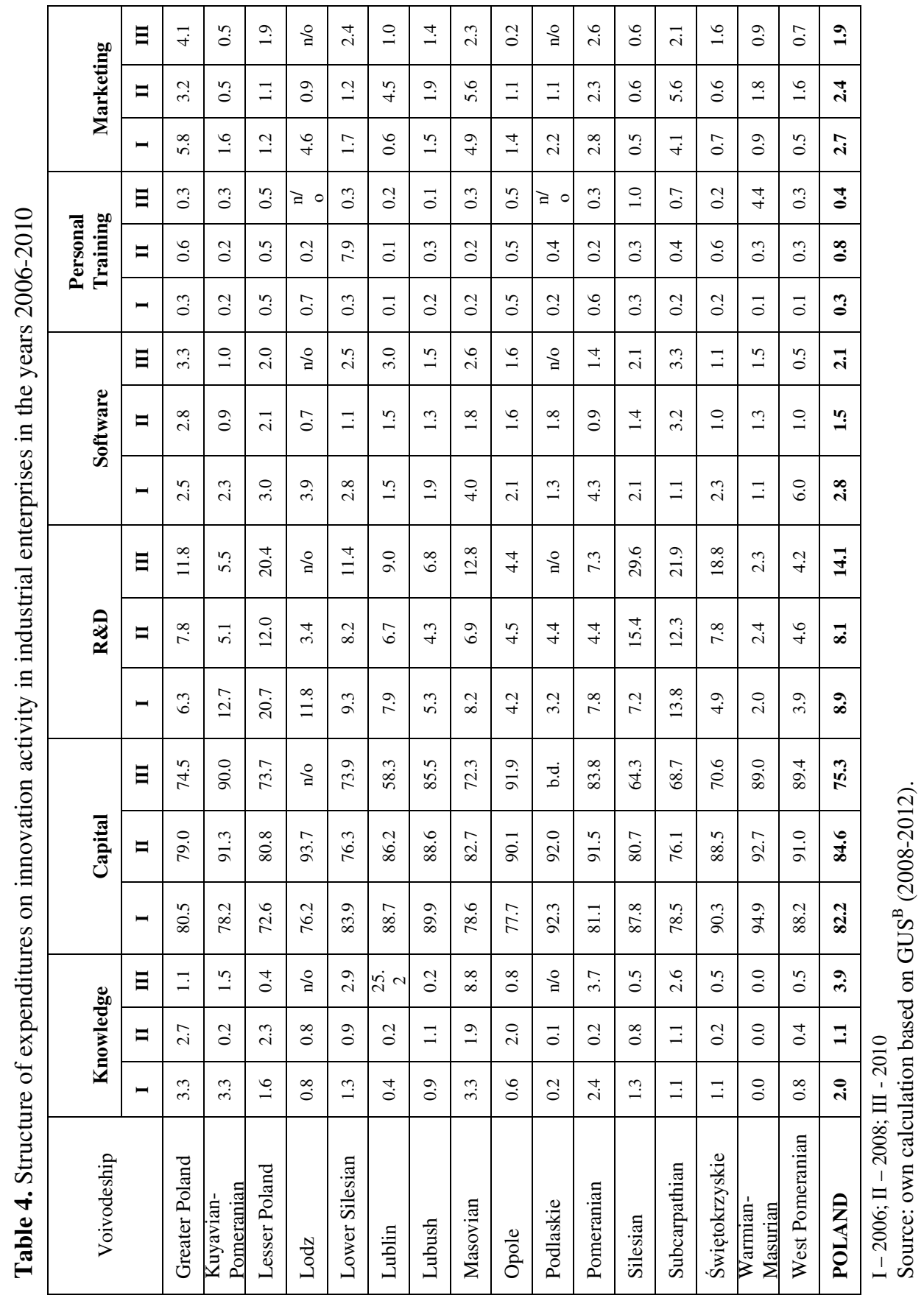




\section{Types of implemented innovations}

The literature distinguishes four types of innovations:

- technological product innovation - the implementation of new or significantly improved products or services in terms of their features or application,

- technological process innovation - the implementation of a new or significantly improved method of production or delivery, as well as distribution and promotion activities for products and services,

- marketing innovation - the implementation of a new concept or a marketing strategy which will be associated with changes in one or more areas of marketing mix: product, packaging, distribution, promotion and pricing strategy,

- organisational innovation - the implementation of a new organisational method.

The results of innovative activities indicate that in the years 2004-2010 a decrease in innovation activity of industrial enterprises was accompanied by reorientation of the types of innovations introduced.

In the first of the analysed periods (2004-2006), the highest percentage of companies allocated funds to organisational innovations. This type of activity was dominant in 15 voivodeships (see Table 5). The Podlaskie Voivodeship, in which funds were allocated to process innovations, was the only exception. In subsequent years, the emphasis shifted from organisational innovations to process and marketing ones. In six voivodeships (KuyavianPomeranian, Lublin, Lubush, Świętokrzyskie, Warmian-Masurian and West Pomeranian) process innovations dominated and in eight voivodeships marketing innovations were dominant. In the Masovian Voivodeship, the intensity of marketing innovations was the same as the intensity of organisational ones (14.2\%), while in the Podlaskie Voivodeship it equalled that of product innovations (12.8\%). Only in two voivodeships (Lower Silesian and Pomeranian) organisational innovations still prevailed.

The reorientation of the types of innovation activities was also accompanied by a decrease in disparities among individual types of innovation. While in 2004-2006 the differences between organizational innovations (most often implemented) and the other types exceeded even 10pp, in subsequent years, that difference was reduced to about $3 \mathrm{pp}$. The disparities among the voivodeships in terms of fund allocation to different types of innovation were also reduced (from $10 \mathrm{pp}$. to $5 \mathrm{pp}$.). 


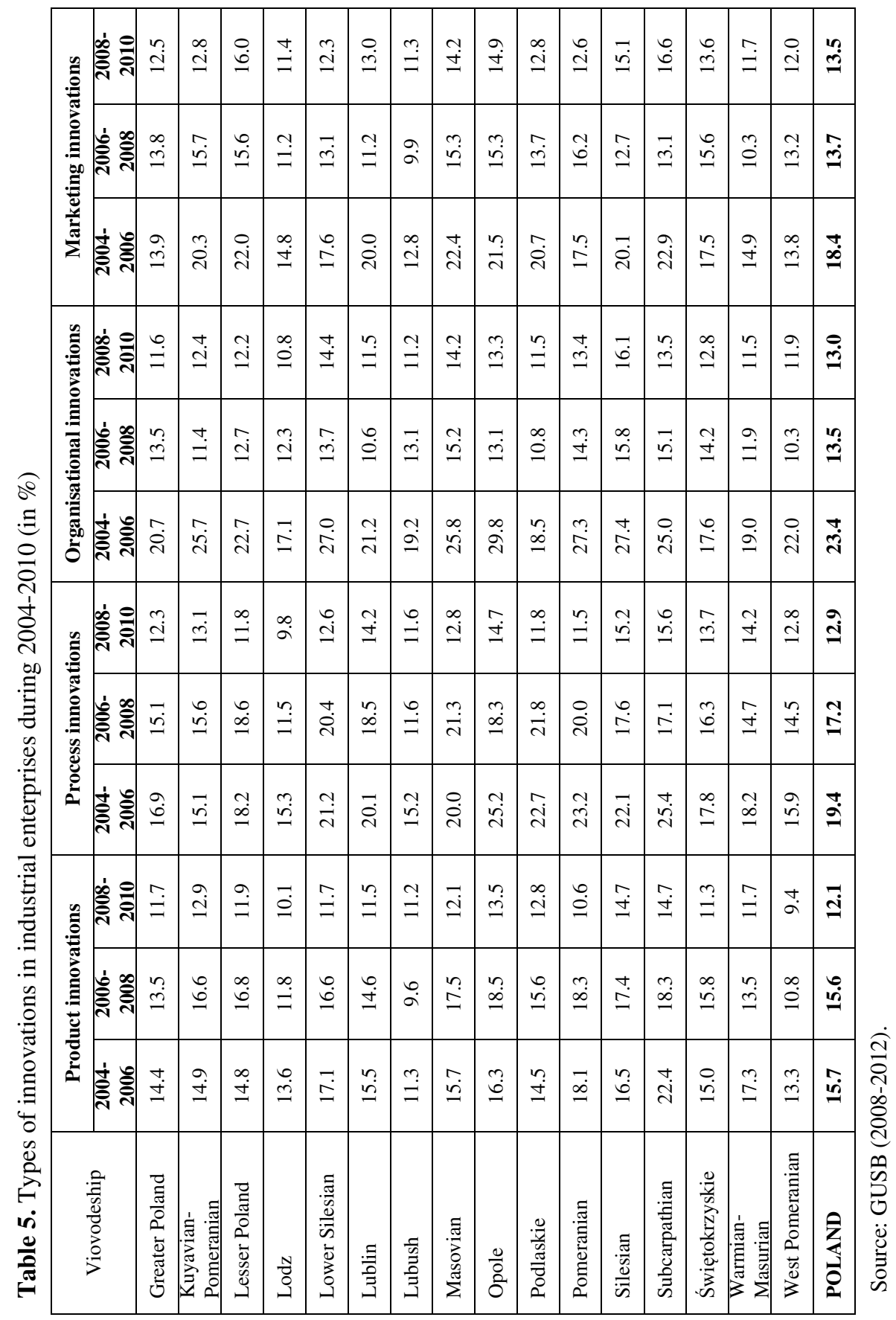




\section{Objective of innovation activities}

Objectives of innovation activity of enterprises are usually considered in terms of three areas:

- product - increasing the range of products, entering new markets, increasing the share in the existing markets, improvement of product quality, replacing obsolete products,

- process - increased production flexibility and production capacity, reduction of labor costs, as well as material and energy consumption per unit of product, replacing outdated processes,

- other results - protecting the environment, improving safety, following regulations, meeting norms and standards.

During the analysed period, the most important objective of introducing innovations by Polish industrial enterprises was the improvement of quality of products and services (see Table 6). In the years 2004-2006, more than $40 \%$ entities from 11 voivodeships declared great significance of this objective. In the case of the Warmian-Masurian Voivodeship, increased production capacity was primarily pointed to as significant $(39.5 \%)$, at the same time quality improvement was seen as slightly less important (39.2\%). Enterprises from the Lodz, Lesser Poland, Podlaskie and Great Poland Voivodeships pointed most often to an increased range of products and services.

In the years 2008-2010 (compared to the years 2004-2008), a growing number of companies declared great importance of quality improvement. The Lubush Voivodeship, in which the share of enterprises declined from $51.2 \%$ to $50.7 \%$, was the only exception. At the same time, there was an increase in the significance of improvement of the range of products and services. This objective was deemed the most important (the highest number of responses) by enterprises from 9 voivodeships. In the case of the other regions (the Lubush, Masovian, Opole, Subcarpathian, Silesian, Świętokrzyskie and Warmian-Masurian Voivodeships), the improvement in quality of products and services still prevailed, though the differences in the number of responses were small.

It is worth noting that during the six analyzed years the role of marketing objectives (entering the market and an increased market share) grew. In most of the voivodeships, this objective ranked as the third. The Lublin and Lubush Voivodeships, in which replacing obsolete products and/or outdated processes was more important, were the exceptions. The importance of process objectives, including the reduction of labor costs (more than 2-fold increase in the Lower Silesian and Lublin Voivodeships), also increased. 
Regional Differences in Innovation Activities of Industrial... 87

\begin{tabular}{|c|c|c|c|c|c|c|c|c|c|c|c|c|c|c|c|c|c|c|c|}
\hline 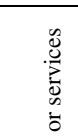 & 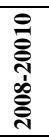 & $\frac{\dot{*}}{\vec{n}}$ & $\overrightarrow{\vec{f}}$ & $\underset{\text { Ni }}{\tilde{n}}$ & "n & $\frac{a}{n}$ & $\stackrel{\circ}{\vec{n}}$ & $\hat{i}$ & $\hat{\text { in }}$ & $\begin{array}{l}n \\
8 \\
8\end{array}$ & 官 & $\stackrel{\infty}{\mathfrak{f}}$ & $\stackrel{+}{\dot{n}}$ & $\underset{\stackrel{+}{f}}{\stackrel{+}{*}}$ & $\overrightarrow{\vec{n}}$ & ?̊. & $\stackrel{\circ}{\circ}$ & ?ึ: & 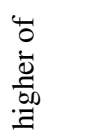 \\
\hline $\begin{array}{l}z \\
0 \\
0 \\
0 \\
0 \\
0 \\
3\end{array}$ & 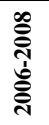 & 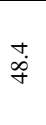 & $\begin{array}{l}3 \\
\stackrel{3}{n} \\
i n\end{array}$ & $\begin{array}{l}0 \\
\text { in }\end{array}$ & $\overrightarrow{\dot{H}}$ & $\vec{q}$ & $\vec{\sim}$ & ?n. & $\begin{array}{l}\infty \\
\tilde{n} \\
n\end{array}$ & $\begin{array}{l}\infty \\
\infty \\
\stackrel{\infty}{+}\end{array}$ & గn & \begin{tabular}{l}
$n$ \\
\multirow{H}{*}{}
\end{tabular} & 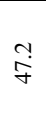 & $\begin{array}{l}m \\
\infty \\
i n\end{array}$ & $\vec{\infty}$ & $\begin{array}{l}0 \\
\dot{b}\end{array}$ & గn & in & 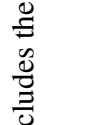 \\
\hline 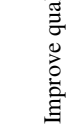 & 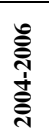 & $\vec{\delta}$ & $\overline{\vec{J}}$ & $\begin{array}{l}\infty \\
\stackrel{\infty}{\infty} \\
\end{array}$ & $\stackrel{F}{\vec{F}}$ & $\stackrel{\grave{y}}{\stackrel{y}{y}}$ & $\frac{9}{\vec{\gamma}}$ & $\frac{N}{n}$ & $\overrightarrow{\dot{\sigma}}$ & $\stackrel{\circ}{\ddot{f}}$ & $\overrightarrow{\dot{q}}$ & $\ddot{q}$ & $\stackrel{\vartheta}{\text { j̀ }}$ & $\begin{array}{l}0 \\
\infty \\
\infty \\
m\end{array}$ & $\begin{array}{l}m \\
\text { pr }\end{array}$ & $\ddot{n}$ & $\begin{array}{l}\dot{b} \\
\ddot{n}\end{array}$ & $\hat{\sigma}$ & 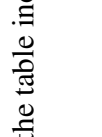 \\
\hline 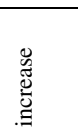 & 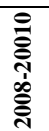 & $\stackrel{n}{q}$ & $\stackrel{+}{\underset{f}{*}}$ & $\ddot{q}$ & $\stackrel{\vec{\gamma}}{\ddot{\gamma}}$ & $\begin{array}{l}0 \\
\dot{q}\end{array}$ & $\overrightarrow{\dot{q}}$ & $\hat{\dot{m}}$ & $\begin{array}{l}3 \\
\dot{q} \\
\dot{q}\end{array}$ & $\frac{m}{n}$ & 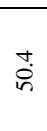 & $\stackrel{n}{q}$ & $\begin{array}{l}\stackrel{0}{\forall} \\
\vec{\forall}\end{array}$ & $\overrightarrow{\dot{z}}$ & $\stackrel{\circ}{\vec{\forall}}$ & $\vec{q}$ & $\stackrel{m}{\forall}$ & 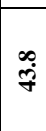 & 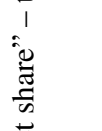 \\
\hline 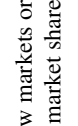 & 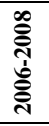 & $\begin{array}{l}\dot{m} \\
\dot{m}\end{array}$ & $\begin{array}{l}\infty \\
\stackrel{\rho}{ }\end{array}$ & 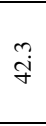 & $\vec{q}$ & $\begin{array}{l}\stackrel{a}{\rho} \\
\dot{m}\end{array}$ & $\begin{array}{l}\infty \\
\infty \\
\infty \\
\infty\end{array}$ & $\stackrel{\infty}{\dot{m}}$ & $\frac{a}{m}$ & $\stackrel{\text { Y }}{\underset{f}{f}}$ & $\begin{array}{l}b \\
\dot{\sigma} \\
\dot{\sigma}\end{array}$ & 字 & 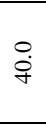 & 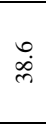 & $\stackrel{\circ}{\ddot{\gamma}}$ & ñ & $\overrightarrow{\dot{p}}$ & $\stackrel{\leftrightarrow}{\dot{\sigma}}$ & 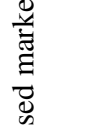 \\
\hline 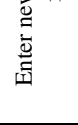 & 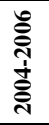 & $\stackrel{\circ}{\text { @ं }}$ & $\stackrel{m}{\stackrel{n}{\sim}}$ & $\stackrel{m}{\infty}$ & $\stackrel{\tilde{i}}{\tilde{i}}$ & $\stackrel{\infty}{\stackrel{\sim}{\Delta}}$ & $\begin{array}{l}0 \\
\text { ते }\end{array}$ & $\vec{m}$ & $\frac{\dot{m}}{\dot{m}}$ & $\frac{\vec{m}}{.}$ & 商 & $\vec{m}$ & 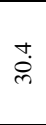 & $\stackrel{a}{\partial}$ & $\begin{array}{l}0 \\
\text { ले }\end{array}$ & $\begin{array}{l}0 \\
\infty \\
\infty\end{array}$ & $\hat{\stackrel{i}{~}}$ & के & 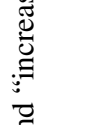 \\
\hline 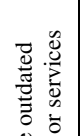 & 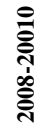 & 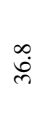 & "n & ra & $\begin{array}{l}\dot{0} \\
\dot{m}\end{array}$ & 官 & $\overrightarrow{\widetilde{r}}$ & ஷे. & 吕 & $\stackrel{+}{\dot{g}}$ & $\stackrel{m}{m}$ & $\ddot{\ddot{~}}$ & $\vec{\infty}$ & $\stackrel{m}{m}$ & $\stackrel{n}{\stackrel{n}{m}}$ & $\underset{\mathfrak{I}}{\stackrel{N}{J}}$ & $\frac{n}{m}$ & $\stackrel{\infty}{\infty}$ & $\begin{array}{l}\hat{\Xi} \\
\stackrel{\Xi}{0} \\
\hat{U}\end{array}$ \\
\hline 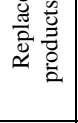 & 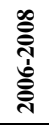 & ণ্ণ & $\stackrel{\infty}{\ddot{f}}$ & $\overrightarrow{\text { ले }}$ & $\stackrel{\text { fे }}{\text {. }}$ & ?n & $\vec{b}$ & $\stackrel{\infty}{m}$ & $\vec{D}$ & $\begin{array}{l}n \\
\infty \\
\infty \\
i\end{array}$ & in & ñ & $\stackrel{\dot{m}}{\dot{m}}$ & $\vec{m}$ & $\begin{array}{l}\infty \\
\stackrel{q}{q}\end{array}$ & $\stackrel{m}{\forall}$ & $\stackrel{\infty}{\vec{\forall}}$ & $\stackrel{m}{m}$ & 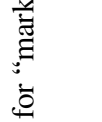 \\
\hline 岕 & 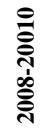 & $\stackrel{\infty}{\stackrel{\infty}{n}}$ & $\stackrel{\infty}{\stackrel{\infty}{n}}$ & $\vec{n}$ & $\begin{array}{l}\infty \\
\stackrel{\leftrightarrow}{\circ}\end{array}$ & $\vec{n}$ & $\stackrel{\dot{0}}{\stackrel{\infty}{+}}$ & 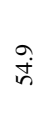 & $\begin{array}{l}\infty \\
\stackrel{+}{+}\end{array}$ & $\stackrel{\vec{r}}{i n}$ & $\stackrel{\sim}{3}$ & $\stackrel{r}{\stackrel{\infty}{+}}$ & in & $\begin{array}{l}n \\
b \\
b\end{array}$ & $\frac{n}{\sim}$ & $\stackrel{\stackrel{\vartheta}{r}}{r}$ & $\overrightarrow{\vec{n}}$ & in & $\begin{array}{l}\frac{0}{0} \\
\frac{5}{0} \\
0 \\
0 \\
0\end{array}$ \\
\hline 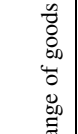 & 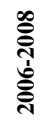 & $\begin{array}{l}\dot{q} \\
\ddot{q}\end{array}$ & $\stackrel{\text { }}{\infty}$ & $\begin{array}{l}\infty \\
i n \\
i n\end{array}$ & $\stackrel{\circ}{\circ}$ & $\stackrel{\stackrel{N}{n}}{\stackrel{n}{n}}$ & $\stackrel{\stackrel{\leftrightarrow}{\mathrm{i}}}{\text { }}$ & $\overrightarrow{\tilde{g}}$ & ì. & ?a & $\begin{array}{l}0 \\
\dot{f} \\
\dot{f}\end{array}$ & $\stackrel{\infty}{\infty}$ & $\begin{array}{c}m \\
\infty \\
\infty\end{array}$ & $\stackrel{+}{\stackrel{\sim}{n}}$ & $\stackrel{m}{n}$ & $\stackrel{0}{\stackrel{1}{n}}$ & $\begin{array}{l}0 \\
\dot{q}\end{array}$ & in & 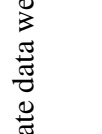 \\
\hline 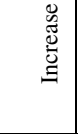 & 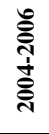 & $\stackrel{\grave{y}}{\breve{y}}$ & 仓े & 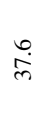 & $\stackrel{\odot}{\stackrel{f}{\gamma}}$ & 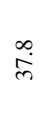 & $\hat{\dot{q}}$ & ?n & $\begin{array}{c}m \\
\infty \\
\infty\end{array}$ & $\vec{m}$ & ্ָডে & $\stackrel{\circ}{\dot{m}}$ & 㒸 & 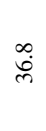 & 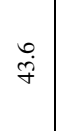 & ભ̀ & $\stackrel{m}{\stackrel{m}{n}}$ & $\stackrel{\oplus}{\infty}$ & 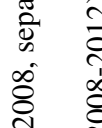 \\
\hline 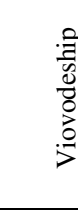 & & 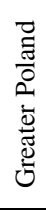 & 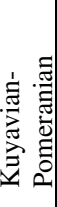 & 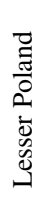 & 공 & 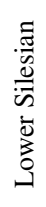 & 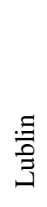 & 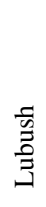 & 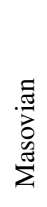 & $\begin{array}{l}\frac{0}{0} \\
\text { مै }\end{array}$ & $\begin{array}{l}\frac{0}{\frac{\pi}{0}} \\
\frac{\tilde{g}}{\tilde{z}} \\
0\end{array}$ & 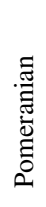 & $\begin{array}{l}\frac{.0}{0} \\
\frac{0}{30} \\
\frac{0}{5}\end{array}$ & 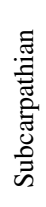 & 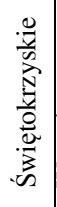 & 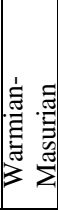 & 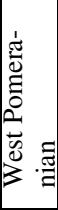 & 甚 & 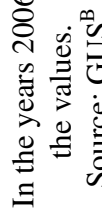 \\
\hline
\end{tabular}




\begin{tabular}{|c|c|c|c|c|c|c|c|c|c|c|c|c|c|c|c|c|c|c|}
\hline \multirow{3}{*}{ 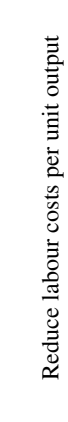 } & 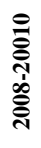 & $\stackrel{\text { m }}{\stackrel{\sim}{v}}$ & ț. & $\begin{array}{l}\infty \\
\dot{n}\end{array}$ & $\grave{\tilde{\lambda}}$ & 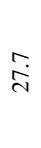 & îj & 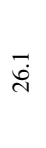 & $\begin{array}{l}0 \\
\text { ì }\end{array}$ & $\stackrel{+}{\infty}$ & $\overrightarrow{\mathrm{i}}$ & $\stackrel{\partial}{\partial}$ & $\underset{\tilde{\lambda}}{\tilde{\lambda}}$ & $\stackrel{+}{\text { ते }}$ & ỹ & $\begin{array}{l}0 \\
\dot{d} \\
\dot{i}\end{array}$ & iे & $\stackrel{n}{\dot{I}}$ \\
\hline & 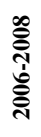 & $\stackrel{\circ}{\text { iे }}$ & $\begin{array}{l}\text { H̃ } \\
\text { ले }\end{array}$ & ì & $\begin{array}{l}n \\
n \\
n\end{array}$ & $\stackrel{\circ}{+}$ & $\begin{array}{l}\text { iे } \\
\text { m. }\end{array}$ & $\stackrel{\infty}{\stackrel{\sim}{\sim}}$ & $\stackrel{\circ}{\dot{d}}$ & $\hat{i}$ & $\frac{a}{m}$ & $\frac{0}{\dot{m}}$ & $\begin{array}{l}\text { ָै } \\
\ddot{n}\end{array}$ & $\overrightarrow{\text { ते }}$ & $\underset{\text { m. }}{\stackrel{t}{m}}$ & $\hat{i}$ & $\begin{array}{l}\infty \\
\dot{m} \\
\dot{m}\end{array}$ & $\underset{\dot{\Phi}}{+}$ \\
\hline & 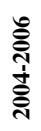 & $\dot{\vec{g}}$ & 导 & 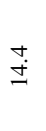 & 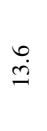 & $\stackrel{n}{I}$ & 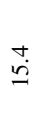 & $\stackrel{\text { m }}{ \pm}$ & 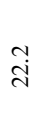 & $\overrightarrow{0}$ & $\stackrel{\sim}{\stackrel{\sim}{d}}$ & 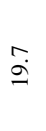 & $\overrightarrow{\ddot{\theta}}$ & $\begin{array}{l}\stackrel{\bullet}{\mathrm{I}} \\
\stackrel{-}{ }\end{array}$ & $\stackrel{\circ}{\stackrel{\infty}{\infty}}$ & $\stackrel{\infty}{\stackrel{0}{\varrho}}$ & $\hat{a}$ & సֶ. \\
\hline \multirow{3}{*}{ 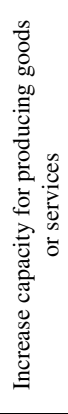 } & 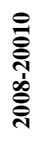 & $\overrightarrow{\mathrm{m}}$ & $\underset{\substack{0 \\
m \\
m}}{ }$ & $\stackrel{\sim}{n}$ & $\ddot{m}$ & $\stackrel{i}{m}$ & $\overrightarrow{\dot{q}}$ & $\stackrel{\circ}{\stackrel{r}{q}}$ & $\vec{m}$ & $\stackrel{\vec{r}}{\stackrel{r}{*}}$ & $\frac{\vartheta}{\vec{\gamma}}$ & के & $\stackrel{n}{\dot{m}}$ & $\hat{i}$ & $\hat{\delta}$ & $\ddot{r}$ & $\vec{g}$ & กั \\
\hline & 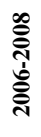 & : & $\stackrel{n}{\forall}$ & $\stackrel{\vec{f}}{\dot{q}}$ & $\stackrel{m}{q}$ & $\begin{array}{l}0 \\
\dot{m}\end{array}$ & $\stackrel{m}{m}$ & $\hat{m}$ & $\hat{q}$ & $\underset{m}{\stackrel{1}{m}}$ & $\begin{array}{l}\dot{0} \\
\dot{y}\end{array}$ & $\hat{i}$ & ֻُ & $\begin{array}{l}\dot{b} \\
\dot{m} \\
\dot{m}\end{array}$ & $\stackrel{\circ}{\stackrel{\sim}{q}}$ & $\begin{array}{l}m \\
\infty \\
i n\end{array}$ & $\vec{g}$ & $\stackrel{\ominus}{\dot{g}}$ \\
\hline & 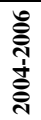 & $\vec{m}$ & $\overrightarrow{\vec{i}}$ & $\begin{array}{l}0 \\
\ddot{d}\end{array}$ & $\stackrel{0}{\underset{\lambda}{d}}$ & ते & $\begin{array}{l}n \\
\stackrel{n}{8}\end{array}$ & $\vec{m}$ & 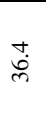 & $\frac{\stackrel{N}{m}}{n}$ & 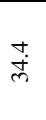 & 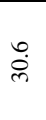 & $\underset{n}{n}$ & $\begin{array}{l}\stackrel{0}{i} \\
\stackrel{i}{ }\end{array}$ & $\begin{array}{l}0 \\
\text { in }\end{array}$ & $\begin{array}{l}n \\
\text { ma }\end{array}$ & $\vec{n}$ & $\stackrel{\circ}{\dot{m}}$ \\
\hline \multirow{3}{*}{ 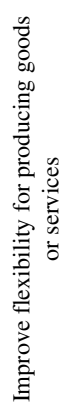 } & 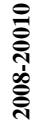 & $\stackrel{\circ}{\stackrel{0}{0}}$ & $\frac{\circ}{\dot{m}}$ & $\underset{\infty}{\sim}$ & $\begin{array}{l}\dot{\omega} \\
\stackrel{\sim}{\sim}\end{array}$ & $\stackrel{\infty}{\dot{m}}$ & $\stackrel{s}{m}$ & ?ִ & ڤั & $\hat{\vec{j}}$ & $\underset{\text { m}}{\stackrel{m}{n}}$ & $\stackrel{\infty}{\stackrel{+}{d}}$ & $\stackrel{\circ}{\dot{\omega}}$ & $\stackrel{\circ}{\dot{\sim}}$ & $\stackrel{i}{m}$ & ֻ̊ & min & 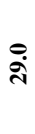 \\
\hline & 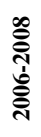 & $\hat{\vec{i}}$ & $\frac{\circ}{\dot{m}}$ & $\stackrel{\stackrel{N}{m}}{m}$ & $\stackrel{b}{\dot{m}}$ & 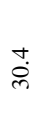 & तે & $\ddot{\sim}$ & $\begin{array}{l}n \\
\stackrel{n}{n}\end{array}$ & ֶֶ. & $\stackrel{?}{\vec{\gamma}}$ & má & $\vec{\sim}$ & ت̆ & $\overrightarrow{\text { ले }}$ & $\begin{array}{l}\dot{b} \\
\dot{m}\end{array}$ & $\begin{array}{l}\dot{0} \\
\dot{\rho}\end{array}$ & 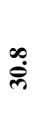 \\
\hline & 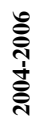 & $\stackrel{+}{d}$ & $\stackrel{m}{\infty} \underset{\infty}{\infty}$ & $\hat{\stackrel{i}{~}}$ & $\stackrel{m}{\infty}$ & $\stackrel{m}{\vec{\lambda}}$ & $\stackrel{\overbrace{}}{\stackrel{\sim}{d}}$ & $\begin{array}{l}\infty \\
\stackrel{\infty}{0}\end{array}$ & $\stackrel{\stackrel{2}{\sim}}{\stackrel{n}{n}}$ & $\hat{\vec{\lambda}}$ & $\stackrel{\infty}{\infty}$ & $\stackrel{0}{\vec{N}}$ & 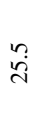 & בु & $\stackrel{\vec{\Delta}}{\vec{\lambda}}$ & İ & ?ִ. & $\stackrel{\text { Tे }}{\mathrm{I}}$ \\
\hline
\end{tabular}

ᄒํ

0
0
0
0
0
0
0
0
0
0
0

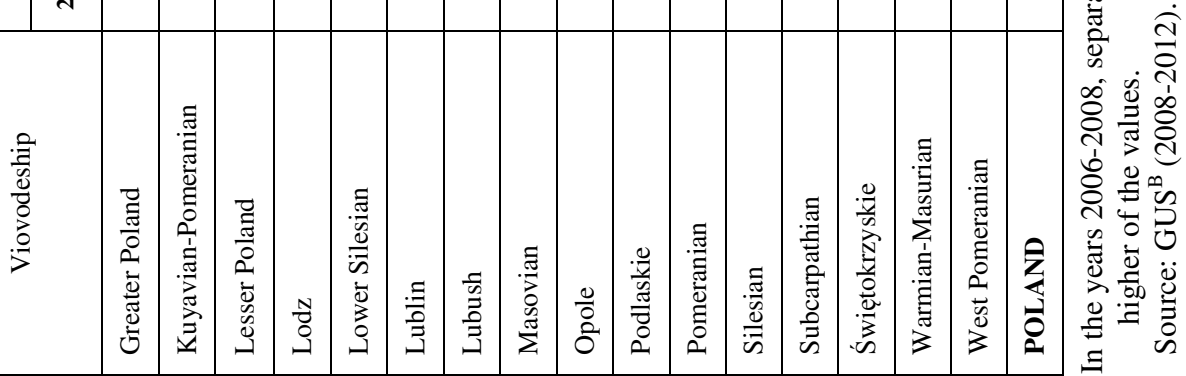




\section{Effects of innovation activity}

From the point of view of innovation policy, its effectiveness, i.e. its impact on output, productivity and employment, is of particular importance. In accordance with the guidelines of the Oslo Manual, the main criterion of assessment of effects of innovation activity is the share in total sales revenue of revenues from the sale of new or significantly improved products or services in the past three years.

The basic prerequisite for innovation is the element of novelty that can be considered at three levels:

- novelty for company - product, process, organisational and marketing methods already exist on the market, however, for this particular company they are new or significantly improved,

- novelty for the market - the company has implemented this particular enterprise as the first on the market or in the given sector,

- novelty on the world scale - introduction of innovations for the first time in all markets and in all sectors, both domestically and internationally.

The results of innovative activities indicate that in the years 2004-2010 Polish industrial enterprises recorded an increasingly smaller share of revenues from sales of new or significantly improved products (a decline from $13.1 \%$ to $11.4 \%$ ). A positive development, however, was an increase in the share of products new to the market (from $5.9 \%$ to $7.1 \%$ ).

The analysis of results of innovation activity in different voivodeships indicates significant disparities. In the analyzed period, the largest share of revenues from sales of new or significantly improved products in total sales revenue was recorded among industrial enterprises from the Pomeranian voivodeship (see Table 7). Additionally, those entities recorded the highest increase in sales of new products (from 25.5\% in the years 2004-2006 to $43.4 \%$ in the years 2008-2010), as well as the largest share of products new to the market (respectively $19.9 \%$ and $42.2 \%$ ).

The poorest results of innovation activity could be observed among the enterprises from the West Pomeranian voivodeship. Those entities were characterised by the smallest share of innovative products, both for the market and for the company. In addition, there was a steady decrease in the share of revenues from the sale of new products, particularly the ones new to the market (from $3.7 \%$ to 1.9\%). The Lublin, Lubush, Podlaskie and Opole voivodeships were also characterised by low innovativeness. 
Table 7. Revenues from sales of new or significantly improved products in the years 2004-2010 (in \% of total turnover)

\begin{tabular}{|c|c|c|c|c|c|c|c|c|c|}
\hline \multirow[b]{2}{*}{ Voivodeship } & \multicolumn{3}{|c|}{ Total } & \multicolumn{3}{|c|}{$\begin{array}{c}\text { New to the } \\
\text { market }\end{array}$} & \multicolumn{3}{|c|}{$\begin{array}{c}\text { Only new to the } \\
\text { firm }\end{array}$} \\
\hline & 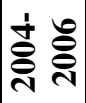 & ஓ̊ & 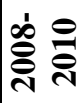 & 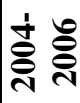 & ஜ્ণ & 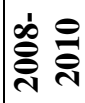 & ఫ્ণ & 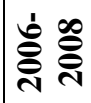 & 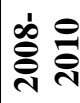 \\
\hline Lower Silesian & 7.9 & 10.5 & 6.0 & 3.1 & 7.1 & 3.6 & 4.7 & 3.5 & 2.4 \\
\hline Kuyavian-Pomeranian & 6.6 & 15.0 & 14.7 & 2.7 & 4.6 & 3.6 & 3.9 & 10.4 & 11.1 \\
\hline Lublin & 7.8 & 6.2 & 3.4 & 4.5 & 4.1 & 1.7 & 3.3 & 2.1 & 1.7 \\
\hline Lubush & 12.2 & 15.5 & 4.5 & 7.0 & 9.1 & 1.4 & 5.1 & 6.4 & 3.0 \\
\hline Lodz & 8.7 & 8.0 & 6.7 & 2.4 & 3.3 & 1.5 & 6.3 & 4.7 & 5.2 \\
\hline Lesser Poland & 10.6 & 13.9 & 10.6 & 5.9 & 9.7 & 6.8 & 4.8 & 4.2 & 3.8 \\
\hline Masovian & 19.7 & 13.5 & 8.5 & 5.5 & 4.8 & 5.6 & 14.2 & 8.7 & 2.9 \\
\hline Opole & 6.4 & 8.5 & 5.3 & 3.5 & 5.8 & 3.7 & 2.9 & 2.7 & 1.6 \\
\hline Subcarpathian & 13.1 & 13.5 & 8.5 & 5.8 & 5.3 & 4.2 & 7.3 & 8.1 & 4.4 \\
\hline Podlaskie & 4.3 & 8.5 & 5.0 & 1.4 & 5.4 & 2.8 & 2.9 & 3.2 & 2.2 \\
\hline Pomeranian & 25.2 & 28.0 & 43.4 & 19.9 & 24.8 & 42.2 & 5.2 & 3.2 & 1.2 \\
\hline Silesian & 11.9 & 11.6 & 12.9 & 6.5 & 5.1 & 6.2 & 5.3 & 6.4 & 6.7 \\
\hline Świętokrzyskie & 7.3 & 9.2 & 5.7 & 4.4 & 4.9 & 2.9 & 2.9 & 4.3 & 2.9 \\
\hline Warmian-Masurian & 10.9 & 13.4 & 10.7 & 4.3 & 3.3 & 2.0 & 6.7 & 10.1 & 8.7 \\
\hline Greater Poland & 9.5 & 8.3 & 11.2 & 4.2 & 4.4 & 5.3 & 5.3 & 3.9 & 5.9 \\
\hline West Pomeranian & 6.5 & 8.6 & 2.9 & 3.7 & 3.2 & 1.9 & 2.7 & 5.4 & 1.0 \\
\hline POLAND & 13.1 & 12.4 & 11.3 & 5.9 & 6.5 & 7.1 & 7.2 & 5.9 & 4.3 \\
\hline
\end{tabular}

Source: GUS ${ }^{\mathrm{B}}(2008-2012)$.

The Kuyavian-Pomeranian voivodeship is also worth noting, as initially (2004-2006) it was the weakest - the companies operating in that region had the lowest percentage of revenues from sales of new or significantly improved products. An effective innovation policy meant, however, that in the years 2008-2010 the share of revenues from the sale of innovative products more than doubled (from 6.6\% to 14.7\%), earning the region the second place in the national ranking (after the Pomeranian voivodeship). The disadvantage, however, is that that increase was primarily due to sales of products new to the company, and not to the market.

Enterprises from the Masovian voivodeship were also characterized by relatively low efficiency. Despite the highest increase in expenditures on innovation activity, those entities recorded a steady decline in the share of revenues from the sale of innovative products (from 19.7\% to 8.5\%). 


\section{Conclusions}

Innovativeness has many important roles to play in the socioeconomic development of enterprises in economic, social, environmental, technical and production areas. In such a situation the need to create new, innovationbased advantages that can ensure long term competitiveness of the entire economy is increasingly recognised.

The conducted analysis indicates that: the level of innovativeness of the Polish economy is still characterised by a low level, the structure of expenditures on innovation is incorrect (companies allocate most funds to the purchase of fixed assets and only approx. $10 \%$ to R\&D), Polish enterprises are selling too few (and ever fewer) innovative products.

Disparities between expenditures on innovation activities in different voivodeships are significant. Three groups of voivodeships can be distinguished - highly innovative (Lower Silesian, Masovian, Pomeranian, Silesian), moderately innovative and poorly innovative (Podlaskie, Świętokrzyskie, Warmian-Masurian, Lubush, Opolskie and West Pomeranian). In addition, the disparities between the most and least innovative voivodeships steadily increase. The most innovative regions increase their advantage, whereas the least innovative ones further decline in this respect. Only the Kuyavian-Pomeranian Voivodeship is an exception, as the share of innovation-active companies and effectiveness of expenditures incurred increases.

In such a situation, it is necessary to implement measures that will: promote the development of modern enterprises and industries susceptible to innovative processes, support innovation activity, remove or reduce the barriers to innovation. These measures should result in an increased level of innovativeness of the Polish economy and in the reduction of disparities among the voivodeships. Attention should be paid to the effectiveness of innovative activity of enterprises, particularly in the cases where it is supported by public funds and does not bring the expected results.

\section{References}

Baruk J. (2006), Zarzqdzanie wiedza i innowacjami, Adam Marszałek, Toruń.

Bogdanienko J., Kuzel M., Sobczak I. (ed.) (2007), Dziatalność innowacyjna przedsiębiorstw w warunkach globalnych, Adam Marszałek, Toruń.

Drucker P. (1992), Innowacje $i$ przedsiębiorczość. Praktyka $i$ zasady, PWE, Warszawa.

European Commission (2003), Communication from the Commission to the Council, the European Parliament, the European Economic and Social Committee and the Committee of the Regions - Innovation policy: updating the Union's 
approach in the context of the Lisbon strategy (COM 2003/112 final), http://eurlex.europa.eu (10.03.2013).

European Commission (2010), Communication from the Commission Europe 2020,

A strategy for smart, sustainable and inclusive growth, Brussels, COM(2010) 2020 final.

GUS $^{\mathrm{A}}$ (2005), Nauka i technika w 2004 r., Warszawa.

GUS $^{\mathrm{A}}$ (2006),Nauka i technika w 2005 r., Warszawa.

GUS $^{\mathrm{A}}$ (2007),Nauka i technika w 2006 r, Warszawa.

GUS $^{\mathrm{A}}$ (2009),Nauka i technika w 2007 r., Warszawa.

GUS $^{\text {A }}$ (2010),Nauka i technika w 2008 r., Warszawa.

GUS $^{\mathrm{A}}$ (2011),Nauka i technika w 2009 r., Warszawa.

GUS $^{\mathrm{A}}$ (2012),Nauka i technika w 2010 r., Warszawa.

GUS $^{\mathrm{B}}$ (2008), Działalność innowacyjna przedsiębiorstw $w$ latach 2004-2006, Warszawa.

GUS $^{\mathrm{B}}$ (2008), Działalność innowacyjna przedsiębiorstw $w$ latach 2006-2009 Warszawa.

GUS $^{\mathrm{B}}$ (2009), Działalność innowacyjna przedsiębiorstw $w$ latach 2006-2008 Warszawa.

GUS $^{\mathrm{B}}$ (2012), Działalność innowacyjna przedsiębiorstw $w$ latach 2008-2010 Warszawa.

Janasz W., Kozioł K. (2007), Determinanty działalności innowacyjnej przedsiębiorstw, PWE, Warszawa.

Kuznets S. (1972), Innovations and Adjustment in Economic Growth, "Swedish Journal of Economics" No 74.

Niedzielski P., Rychlik K. (2006), Innowacje i Kreatywność, Publishing USz, Szczecin.

OECD/European Communities (2005), Oslo Manual: Guidelines for Collecting and Interpreting Innovation Data, 3rd Edition.

Schumpeter J.A. (1960), Teoria rozwoju gospodarczego, PWN, Warszawa.

Stownik języka polskiego, PWN, Warszawa, http://sjp.pwn.pl (1.03.2013)

Stępniak-Kucharska A. (2012), Działalność innowacyjna przedsiębiorstw przemysłowych w Polsce, ,Studia Prawno-Ekonomiczne”, t. LXXXVI.

Szomburg J. (2004), Strategia lizbońska szansa dla Europy, IBnGR, Gdańsk.

Wolak-Tuzimek A., Wolak-Kozera I. (2012), Polityka innowacyjna Unii Europejskiej w okresie kryzysu gospodarczego [in:] Misztal P., Rakowski W. (ed.), Przyszłość integracji europejskiej. Uwarunkowania rozwoju gospodarczego Unii Europejskiej, CeDeWu, Warszawa. 